\title{
Efektifitas Pendekatan Saintifik terhadap Kemampuan Pemecahan Masalah Anak Usia 3-6 Tahun
}

\author{
'Azizah Muthi' Nuryatmawati ${ }^{\varpi_{1}}$, Dimyati ${ }^{2}$ \\ Pendidikan Anak Usia Dini Universitas Negeri Yogyakarta(1), \\ Pendidikan Olahraga, Universitas Negeri Yogyakarta(2) \\ DOI: $10.31004 /$ obsesi.v5i2.1048
}

\begin{abstract}
Abstrak
Penelitian ini bertujuan untuk mengetahui efektivitas pendekatan saintifik terhadap kemampuan pemecahan masalah anak usia 3-6 tahun. Metode penelitian yang digunakan yaitu kuantitatif dengan jenis true eksperiment dan desain pretest-posttes control group. Populasi dan sampel dalam penelitian yaitu anak usia 5-6 tahun TK ABA Thoyibah Banyuanyar dengan jumlah sampel dalam penelitian ini yaitu 51 anak. Teknik pengumpulan data melalui tes wawancara. Validitas instrumen menggunakan pendapat dari jurnal internasional. Reliabilitas instrumen diuji menggunakan rumus alpha yang dibantu dengan aplikasi SPSS 20 for windows. Analisis data menggunakan uji prasarat dan uji hipotesis. Uji prasarat berupa uji normalitas menggunakan rumus shapiro wilk dan uji homogenitas menggunakan levene test for equality variance. Uji hipotesis menggunakan independent sample t-test. Hasil analisis menunjukkan pendekatan saintifik efektiv terhadap kemampuan pemecahan masalah anak usia 3-6 tahun. Anak-anak mampu memberikan solusi terhadap masalah yang anak temua, mengerti sebab akibat masalah terjadi seperti contoh setelah diberikan pembelajaran menggunakan pendekatan saintifik.
\end{abstract}

Kata Kunci: pendekatan saintifik; pemecahan masalah; anak usia 3-6 tahun

\begin{abstract}
This study aims to determine the effectiveness of the scientific approach to problem solving abilities of children aged 3-6 years. The research approach is quantitative with the type of true experiment and the design of the pretest-posttes control group. The population and sample in the study were children aged 5-6 years ABA Thoyibah Banyuanyar Kindergarten with a sample of 51 children. The technique of collecting data through interview tests. The validity of the instrument uses the opinions of international journals. Instrument reliability was tested using alpha formula which was assisted by SPSS 20 for Windows applications. Data analysis using preliminary testing and hypothesis testing. The preliminary test in the form of a normality test using the shapiro wilk formula and the homogeneity test using the levene test for equality variance. Hypothesis testing uses independent sample t-test. The results of the analysis show an effective scientific approach to problem solving abilities of children aged 3-6 years. Children are able to provide solutions to problems that children face, understand the causes of problems occur as examples after being given scientific approach learning.
\end{abstract}

Keywords: scientific approach; problem solving; children aged 3-6 years

Copyright (c) 2019 ‘Azizah Muthi’ Nuryatmawati, Dimyati

$\triangle$ Corresponding author :

Email Address : azizahmuthi36@gmail.com (Yogyakarta, Indonesia)

Received 13 January 2021, Accepted 10 February 2021, Published 18 February 2021

Jurnal Obsesi : Jurnal Pendidikan Anak Usia Dini, 4(2), 2020 | 2071 


\section{PENDAHULUAN}

Pendidikan untuk Anak Usia Dini (PAUD) merupakan pondasi awal yang dalam pelaksanaannya harus dilakukan semaksimal mungkin. Pendidikan Anak Usia Dini merupakan upaya pembinaan yang telah ditunjukkan kepada anak dari sejak lahir hingga usia enam tahun yang dilakukan dengan pemberian rangsangan pendidikan guna membantu pertumbuhan dan perkembangan jasmani maupun rohani bagi anak agar anak mempunyai kesiapan yang lebih matang dalam mengikuti pendidikan yang selanjutnya (Pemerintah Republik Indonesia, 2003). Salah satu keberhasilan dalam sebuah pendidikan yaitu dilihat dari proses pembelajarannya. Pembelajaran bagi anak usia dini harus dikelola dengan baik sesuai dengan kebutuhan dan karakteristik anak, agar nantinya anak dapat mengoptimalkan potensi yang telah mereka miliki. Proses pembelajaran merupakan sarana untuk menstimulasi kecerdasan anak, oleh karena itu, pemilihan strategi, metode, media maupun pendekatan dalam proses pembelajaran harus sesuai dengan tema dan standar kurikulum yang telah diterapkan (Marwah et al., 2018).

Salah satu kurikulum yang telah diterapkan khususnya bagi anak usia dini ialah kurikulum 2013. Kurikulum 2013 ini merupakan kurikulum yang menekankan pembelajarannya dengan pendekatan saintifik dan penilaian autentik (Peraturan Menteri Pendidikan dan Kebudayaan Republik Indonesia Nomor 146 Tahun 2014 Tentang Kurikukum 2013 Pendidikan Anak Usia Dini, 2013). Kurikulum 2013 menekankan pada dimensi pedagogik modern dalam pembelajaran, yaitu menggunakan pendekatan ilmiah (Anshori, 2018). Pendekatan ilmiah (saintifik approach) dalam pembelajaran sebagaimana dimaksud meliputi mengamati, menanya, menalar, mencoba, membentuk jejaring untuk semua mata pelajaran. Kompetensi Inti pada Kurikulum 2013 yang berhubungan dengan pendekatan saintifik adalah Kompetensi Inti 3 yaitu Mengenali diri, keluarga, teman, pendidik, lingkungan sekitar, agama, teknologi, seni, dan budaya di rumah, tempat bermain dan satuan PAUD dengan cara : mengamati dengan indra (melihat, mendengar, membau, merasa, meraba); menanya; mengumpulkan informasi; menalar dan mengomunikasikan melalui kegiatan bermain (Anshori, 2018).

(Lazim, 2013) mendefinisikan pendekatan saintifik adalah proses pembelajaran yang dirancang sedemikian rupa agar peserta didik secara aktif mengonstruksi konsep, hukum atau prinsip melalui tahapan-tahapan mengamati (untuk mengidentifikasi atau menemukan masalah), merumuskan masalah, mengajukan atau merumuskan hipotesis, mengumpulkan data dengan berbagai teknik, menganalisis data, menarik kesimpulan dan mengomunikasikan konsep, hukum atau prinsip yang "ditemukan". Sains adalah sekumpulan pengetahuan yang diperoleh melalui suatu metode tertentu (Juhji, 2016). Sains juga berusaha menguasai alam dan dapat memanfaatkan alam untuk kesejahteraan manusia, meningkatkan taraf hidup, efisiensi dan efektifitas kerja (Van Vreden, 2018) Sains memiliki beberapa fungsi yaitu membantu manusia berpikir dalam pola sistematis, menjelaskan gejala alam, meramalkan gejala alam yang akan terjadi, menguasai alam dan mengendalikan alam, dan melestarikan alam (Hong \& Diamond, 2012). Sains memiliki lima utama (Fleer, 2019) yaitu: 1) Analitis; 2) Logis; 3) Sistematis; 4) Kausatif; 5) Kuantitatif.

Sains merupakan disiplin ilmu yang mempelajari obyek alam dengan metode ilmiah (Sund, 1989) dalam (Sari et al., 2014)). Untuk anak TK, obyek tersebut meliputi benda-benda di sekitar anak dan benda-benda yang sering menjadi perhatian anak. Air, udara, bunyi, api, tanah, tumbuhan, hewan, dan dirinya sendiri merupakan obyek-obyek sains yang sering menjadi perhatian anak. Selain itu Rusman (2015) mengatakan bahwa pendekatan saintifik yaitu pembelajaran yang berbasis fakta/konkrit yang dapat dijelaskan dengan logika berpikir, menginspirasi anak untuk dapat berpikir kritis, mampu menganalisis dan tepat dalam mengidentifikasi, memahami dan memecahkan masalah. Pembelajaran dengan pendekatan saintifik dapat memberikan kontribusi positif untuk meningkatkan kemampuan berpikir kritis pada anak, mengembangkan karakter dan kecerdasan anak sehingga anak dapat memecahkan masalah secara sederhana (Yunita et al., 2019). 
Pemecahan masalah adalah salah satu bagian dari perkembangan kognitif. Tujuan khusus dari pendidikan anak usia dini dari hasil studi adalah agar anak mampu berpikir secara kritis, memberi alasan, memecahkan masalah dan menemukan hubungan sebab akibat (Couchenour \& Chrisman, 2016). Pemecahan masalah merupakan salah satu bagian dari kemampuan kognitif. Piaget dalam Patmonodewo (2000) menyatakan bahwa perkembangan kecerdasan kognitif dipengaruhi oleh faktor kematangan dan pengalaman. Perkembangan kognitif dibuktikan dengan pertumbuhan kemampuan merancang, mengingat, dan mencari penyelesaian masalah yang dihadapi. Hasil studi, pemecahan masalah yang berhasil bergantung pada kemampuan fungsi eksekutif (EF) (misalnya: memori kerja, penghambatan kontrol, fleksibilitas kognitif), yang penting untuk diatur perilaku yang diarahkan pada tujuan (Zelazo, 2015).

Pemecahan masalah merupakan sebuah kemampuan yang harus dimiliki seseorang, karena kegiatan pemecahan masalah menuntut kreatifitas dari setiap individu. (Hudojo, 2001) mengungkapkan bahwa suatu pertanyaan akan menjadi suatu masalah bagi seseorang jika seseorang tersebut tidak mempunyai aturan atau hukum tertentu yang dapat dipergunakan untuk menemukan jawaban pertanyaan tersebut. (Made, 2011) juga berpendapat bahwa pemecahan masalah adalah petunjuk untuk melakukan suatu tindakan yang berfungsi untuk membantu seseorang dalam menyelesaikan suatu permasalahan.

Inti dari kemampuan memecahkan masalah adalah anak dapat menyelesaikan masalah dengan cara membiasakan anak mengerjakan soal-soal yang tidak hanya mengandalkan ingatan, tetapi anak diharapkan mampu mengaitkan dengan situasi nyata (Washington, 1996). Anak diharapkan mampu bereksplorasi dengan benda kongkrit Wolfinger, 1994 dalam Suyanto (2006)). Oleh karena itu, dari penjelasan diatas dapat diketahui bahwa pendekatan saintifik dan kemampuan pemecahan masalah sangatlah berkaitan.

Berbagai macam penelitian yang membahas tentang Pembelajaran saintifik sudah beberapa kali dilakukan, hasil penelitian dari Istiningsih (2014) dengan judul "Relationship Between Religious Consciousnesses With Scientific Learning (Case Study In Islamic Basic School In Malaysia And Indonesia)", penelitian ini untuk mengetahui hubungan kesadaran beragama dengan scientific learning, kesadaran beragama anak didik dapat dilihat dari perilakunya. Dari penelitian ini dihasilkan bahwa sekolah yang memberikan stimulasi dan dorongan yang lebih terhadap perilaku siswa yang menjadikan siswa memiliki perilaku yang baik. Kesadaran beragama berkaitan erat dengan pembelajaran ilmiah, kesadaran beragama dapat menjadi program sekolah untuk meningkatkan pembelajaran ilmiah siswa. Penelitian Yusri (2015), tentang “Keterkaitan Scientific learning dengan kemampuan berpikir kritis (Kajian Proses Pembelajaran di Sekolah Dasar Budi Mulia Dua Sedayu Bantul). Keterkaitan scientific learning skill siswa dan berpikir kritis merupakan pembelajaran yang terdiri dari mengamati, mengklasifikasi, mengkomunikasikan secara bersamaan mempunyai pengaruh terhadap kemampuan berpikir siswa sebesar $68 \%$ dan sisanya 32\% dipengaruhi oleh faktor lain diluar scientific learning skill anak. Penelitian selanjutnya adalah penelitian oleh Marwah et al. (2018) dengan judul "Pendekatan Saintifik dalam Pengembangan Bahasa Anak Di Taman Kanak-Kanak Asoka Kota Makassar" mengatakan bahwa terdapat hubungan pendekatan saintifik dengan perkembangan bahasa anak, dengan pendekatan saintifik memunculkan motivasi anak untuk belajar melalui bermain. Dengan pendekatan saintifik maka perkembangan bahasa anak di TK Asoka dapat ditingkatkan.

Penelitian ini berbeda dengan penelitian sebelumnya, meskipun ada beberapa yang membahas tentang pembelajaran saintifik tetapi belum sepenuhnya fokus pada pembelajaran untuk anak usia dini yang melibatkan keterampilan dalam pemecahan masalah saintifik, untuk itu perlu dilakukan penelitian tentang bagaimana Efektifitas Pendekatan Saintifik Terhadap Kemampuan Pemecahan Masalah Anak Usia 3-6 Tahun.

Berdasarkan wawancara dengan guru kelas di kelompok B1 TK ABA Thoyibah Banyuanyar ditemukan fakta bahwa, kemampuan memecahkan masalah anak masih kurang optimal. Hal tersebut dilihat dari hasil penilaian pratindakan berdasarkan pencapaian 
indikator kinerja penelitian yaitu kemampuan pemecahan masalah anak belum mampu menemukan kesalahan, belum mampu memperkirakan penyebab dan belum mampu membuat keputusan. Oleh sebab itu dapat dikatakan bahwa kemampuan penyelesaian masalah anak di kelompok B1 TK ABA Thoyibah Banyuanyar masih rendah atau kurang maksimal. Melihat fenomena tersebut pemilihan metode kemampuan pemecahan masalah pada anak harus melibatkan anak secara langsung agar anak benar-benar memahami masalah yang dihadapi anak tersebut. Dalam meberikan pembelajaran pada anak usia dini haruslah melibatkan keaktifan anak dan mengajak anak untuk secara aktif memberikan pendapat anak.

Melihat tentang permasalahan yang telah terjadi saat ini terhadap anak usia dini, maka penulis tertarik untuk melakukan penelitian terkait tentang Efektifitas Pendekatan Saintifik Terhadap Kemampuan Pemecahan Masalah Anak Usia 3-6 Tahun. Pada penelitian ini bertujuan untuk mengetahui Efektifitas Pendekatan Saintifik Terhadap Kemampuan Pemecahan Masalah Anak Usia 3-6 Tahun.. Harapan dan manfaat secara teoritis dari penelitian ini yaitu dapat dijadikan bahan masukan dan referensi serta motivasi bagi satuan PAUD lainnya dalam penerapan keefektifan pendekatan saintifik terhadap kemampuan pemecahan masalah bagi anak.

\section{METODOLOGI}

Penelitian ini dilakukan di TK ABA Thoyibah Surakarta pada anak usia 3-6 tahun dengan kemampuan pemecahan masalah rendah, tahun ajaran 2020/2021. Peneliti memilih TK ABA Thoyibah Surakarta karena sebelumnya peneliti berkesempatan untuk melakukan magang di TK tersebut kemudian peneliti mendapatkan keluhan dari guru mengenai kemampuan pemecahan masalah anak terutama pada anak yang akan melanjutkan ke Sekolah Dasar masih rendah. Waktu penelitian ini dimulai dari bulan Oktober hingga bulan Desember 2020. Hal ini dikarenakan untuk mempersiapkan anak masuk ke Sekolah Dasar. Agar anak lebih siap menghadapi masalah dengan solusi yang tepat nantinya ketika berada di lingkungan baru.

Penelitian ini menggunakan pendekatan penelitian yaitu kuantitatif dengan jenis true eksperiment dan desain pretest-posttes control group. Pada kelompok eksperimen diberi stimulus dengan menggunakan pendekatan saintifik sedangkan kelompok kontrol menggunakan pembelajaran seperti biasanya sehari-hari yaitu ceramah dan LKA/majalah sekolah.

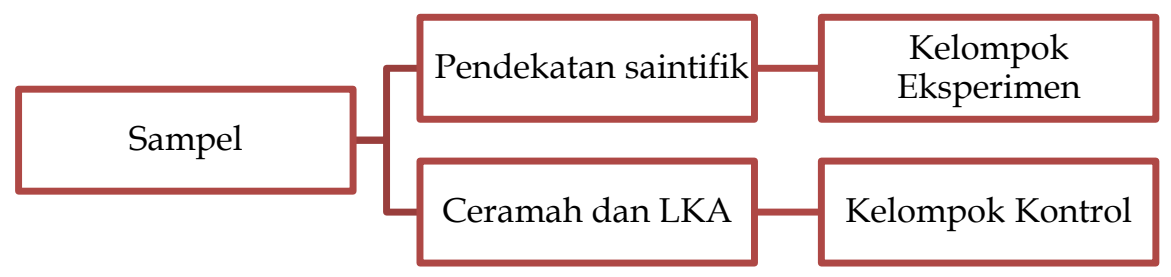

Gambar 1. Desain Penelitian

Populasi dalam penelitian ini adalah seluruh anak kelompok B Taman Kanak-kanak ABA Thoyibah Surakarta yang berusia 5-6 tahun. Peneliti mengambil sampel menjadi grup A dengan jumlah 34 anak dan grup B yang terdiri dari 27 anak. Penelitian ini menggunakan random assignment. Pada metode ini setiap partisipan mempunyai kesempatan yang sama untuk ditempatkan menjadi salah satu grup dan mengalami treatment tertentu. Sampel penelitian yang terdiri dari 51 anak untuk masing-masing kelompok 34 anak dan 27 anak dengan kemampuan pemecahan masalah rendah. Responden dipilih dengan menggunakan pretest serta hasil wawancara dengan guru, dinyatakan kemampuan pemecahan rendah apabila skor hasil pretest dibawah nilai rata-rata kelas.

Langkah-langkah pengambilan sampel dalam penelitian ini yang pertama menentukan populasi dalam penelitian yaitu kelompok B TK ABA Thoyibah yang berusia 5-6 tahun yang memiliki kemampuan pemecahan masalah yang rendah berdasarkan wawancara dengan guru 
dan pretest. Kedua, membagi populasi menjadi dua bagian sehingga terdapat grup A dan grup B. Ketiga, melakukan pengundian kembali untuk menentukan kelompok eksperimen dan kelompok kontrol.

Adapun data yang digunakan dalam penelitian ini adalah kualitatif dan kuantitatif. Dalam penelitian ini penulis menggunakan dua sumber data yaitu: Sumber data primer dalam penelitian ini adalah kepala sekolah, guru dan anak di TK ABA Thoyibah Surakarta. Sumber data sekunder dokumentasi dan hasil pretest dan posttest merupakan sumber data sekunder.

Pengumpulan data pada penelitian ini menggunakan metode observasi atau pengamatan. Observasi dilakukan selama 2 minggu di TK ABA Thoyibah Surakarta terutama pada kelas B1 dan B2. Pengumpulan data pada penelitian ini juga menggunakan metode wawancara. Wawancara ditujukan kepada Kepala Sekolah dan guru kelas. Pengumpulan data pada penelitian ini selain menggunakan metode observasi atau pengamatan dan wawancara juga menggunakan Pretest yang berguna untuk memperkuat hasil dari observasi dan juga wawancara. Pengumpulan data pada penelitian ini selain menggunakan metode observasi atau pengamatan, wawancara dan pretest juga menggunakan posttest untuk mengetahui hasil akhir penelitian. Pengumpulan data pada penelitian juga menggunakan dokumentasi untuk mendukung pengumpulan data yang lainnya. Proses pengumpulan data dokumentasi dilaksanakan selama penelitian berlangsung, yaitu pada bulan April sampai dengan Juni 2018.

Instrumen yang digunakan dibuat sendiri oleh peneliti yang mengacu pada perkembangan kognitif (pemecahan masalah) anak yang bersumber dari penelitian sebelumnya dari Maria dan Maureen pada tahun 2018 dengan 7 skenario pemecahan masalah dengan pendekatan saintifik. Kemudian dikonsultasikan pada ahli di bidang psikologi anak usia dini dan saintifik (expert judgment). Setelah instrumen dinyatakan valid peneliti melakukan uji coba instrumen. Data hasil uji coba selanjutnya diuji validitasnya menggunakan uji daya beda dengan mengorelasikan antara skor item dalam suatu faktor. Kriteria item yang baik dengan batas minimal $\geq 0,3$. Skala uji coba pemecahan masalah terdiri dari 7 item pertanyaan yang dibantu oleh tim peneliti agar responden memahami pertanyaanpertanyaan yang akan dijawab.

Pengujian reliabilitas pada penelitian ini menggunakan internal consistency melalui satu kali uji coba instrumen dikarenakan responden pada penelitian ini adalah anak usia dini. Data yang diperoleh dari hasil uji coba, dianalisis menggunakan SPSS. 20 for windows.

Data yang telah diperoleh kemudian dianalisis menggunakan statistik parametrik. Apabila data sudah dinyatakan normal dan homogen, dilakukan uji hipotesis untuk mengetahui ada tidaknya perbedaan yang signifikan dari perlakuan dalam pendekatan saintifik terhadap kemampuan pemecahan masalah anak dengan melakukan uji $\mathrm{t}(t$-test). Data yang sudah terkumpul ini kemudian diuji dengan menggunakan bantuan SPSS. 20 for windows

Perlakuan diberikan sebanyak 4 (empat) kali dengan kelompok eksperimen menggunakan pembelajaran pendekatan saintifik dan kelompok kontrol menggunakan pembelajaran dengan penugasan perkelompok.

Tabel 1. Desain Penelitian

\begin{tabular}{crrr}
\hline Kelompok & Pretest & Treatment & Posttest \\
\hline $\mathrm{E}$ & $\mathrm{O}_{1}$ & $\mathrm{X}$ & $\mathrm{O}_{2}$ \\
$\mathrm{~K}$ & $\mathrm{O}_{3}$ & & $\mathrm{O}_{4}$ \\
\hline
\end{tabular}

Analisis data menggunakan uji prasarat dan uji hipotesis. Uji prasarat berupa uji normalitas menggunakan rumus shapiro wilk dengan taraf signifikansi $>0,05$ dan uji homogenitas menggunakan levene test for equality variance dengan tingkat signifikansi $>0,05$. Uji hipotesis menggunakan independent sample t-test. Pengolahan data dibantu dengan SPSS 20 for windows. 


\section{HASIL DAN PEMBAHASAN}

Hasil analasis menggunakan teknik statistik deskriptif. Data selengkapnya dapat dilihat pada tabel dibawah.

Tabel 2. Diskripsi Data

\begin{tabular}{lllllll}
\hline & Kelompok & $\mathrm{N}$ & Min & Mak & Mean & Std. Dev \\
\hline Nilai & Eksperimen & 7 & 7,00 & 28,00 & 15,6176 & 5,53236 \\
Pretest & Kontrol & 7 & 7,00 & 22,00 & 15,1481 & 4,33859 \\
Nilai & Eksperimen & 7 & 7,00 & 28,00 & 22,0000 & 4,50589 \\
Posttest & Kontrol & 7 & 14,00 & 26,00 & 21,4444 & 3,87629 \\
\hline
\end{tabular}

Dari tabel 2 dapat dilihat keadaan responden sebelum diberi perlakuan (pretest) dengan sesudah diberikan perlakuan (posttest). Terdapat pengaruh positif, hal tersebut dapat dilihat dari mean yang lebih besar sesudah perlakuan dibandingkan sebelum perlakuan. Pengaruh positif pada penelitian ini terletak pada kemampuan pemecahan masalah anak meningkat, yang ditandai dari kemampuan anak dalam memecahkan masalah dapat memeberikan lebih dari 1 solusi untuk menyelesaikan masalah yang dihadapi.

Penelitian ini menggunakan uji persyaratan analisis yang terdiri dari uji normalitas dan uji homogenitas. Hasil uji normalitas dan homogenitas dapat dilihat pada tabel 3.

Tabel 3. Data Hasil Normalitas dan Homogenitas

\begin{tabular}{llll}
\hline & & Normalitas & Homogenitas \\
\hline Pretest & Eksperimen & 0,054 & 0,117 \\
& Kontrol & 0,067 & \\
\hline Posttest & Eksperimen & 0,059 & 0,682 \\
& Kontrol & 0,082 & \\
\hline
\end{tabular}

Berdasarkan tabel 3 uji normalitas kedua kelompok (sampel) menunjukan bahwa data berdistribusi normal sehingga dapat dinyatakan bahwa sampel yang diambil sudah mewakili populasi yaitu menunjukan signifikansi $>0,05$. Berdasarkan tabel 3 juga maka dapat disimpulkan bahwa data dalam penelitian ini merupakan data homogen yang artinya populasi dalam penelitian ini memiliki variasi yang sama. Untuk lebih jelasnya berikut peneliti paparkan hasil uji Homogenitas.

Uji hipotesis dilakukan dengan menggunakan independent sample t-test. Hasil uji hipotesis dapat dilihat pada tabel 5 .

Tabel 4. Hasil Uji Homogenitas

Test of Homogeneity of Variances

Hasil pretest

\begin{tabular}{|c|c|c|c|}
\hline $\begin{array}{l}\text { Levene } \\
\text { Statistic }\end{array}$ & df1 & df2 & Sig. \\
\hline 2.533 & 1 & 59 & 117 \\
\hline
\end{tabular}

Test of Homogeneity of Variances

Hasil posttest

\begin{tabular}{|c|c|c|c|}
\hline Levene Statistic & df1 & $\mathrm{df} 2$ & Sig. \\
\hline .169 & 1 & 59 & .682 \\
\hline
\end{tabular}


Tabel 5. Hasil Uji Independent Sample T-Test PrettestPosttest

\begin{tabular}{llll}
\hline & Kelompok & Mean & P \\
\hline Sebelum perlakuan & Eksperimen & 15.6176 & 0,446 \\
& Kontrol & 15.1481 & \\
Setelah perlakuan & Eksperimen & 22.0000 & 0,000 \\
& Kontrol & 21.4444 & \\
\hline
\end{tabular}

Dari tabel 4 dapat disimpulkan rata-rata kelompok eksperimen mendapatkan rata-rata yang lebih tinggi dibandingan dengan rata-rata kelas kontrol, sehingga berdasarkan tabel diatas pendekatan saintifik dapat berpengaruh pada pemecahan masalah anak usia 3-6 tahun. Hasil analisis data independent sample t-test dapat dilihat pada lampiran 18

Hasil data diperoleh dari nilai tes unjuk kerja dari anak yang terdiri dari 5 lembar kerja. Kelima nilai kemudian dijumlahkan dan didapat nilai yang kemudian diolah menghasilkan nilai maksimal, nilai minimal, nilai range, rata-rata atau mean, serta standar deviasinya. Data yang diperoleh dari penelitian yang telah dilaksanakan seperti terlihat pada gambar 2 .

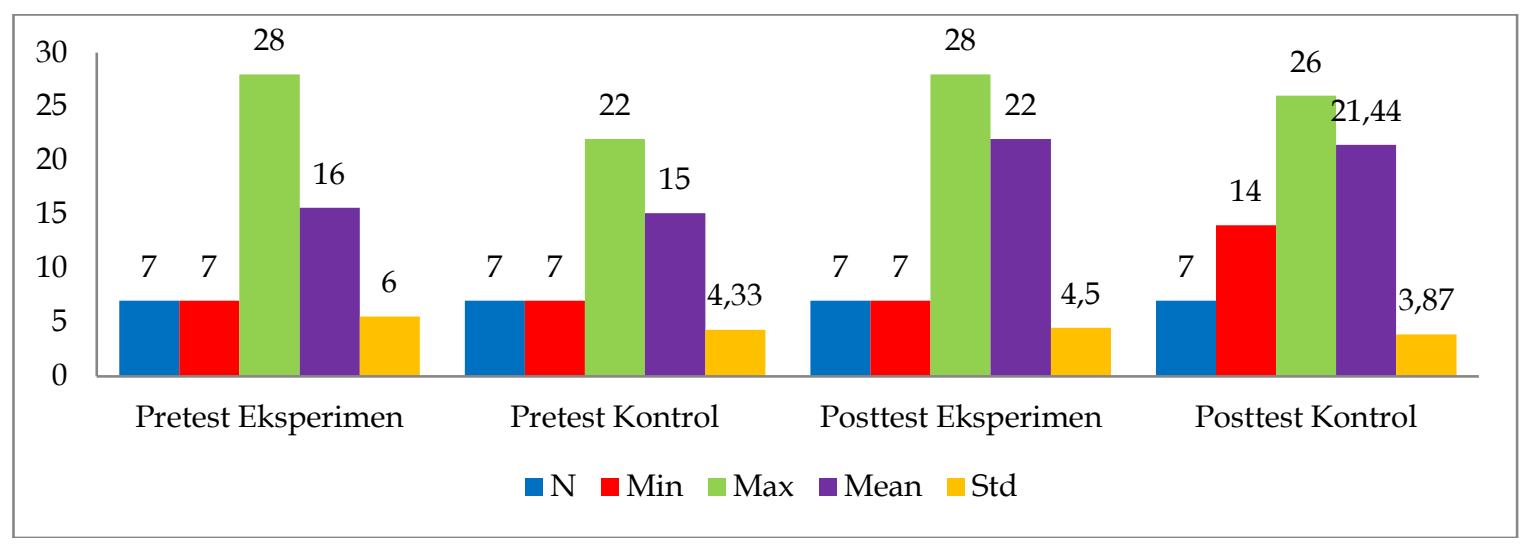

\section{Gambar 2. Distribusi Data}

Berdasarkan gambar 2, distribusi data tersebut dapat diketahui bahwa terdapat perbedaan kelompok eksperimen dan kelompok kontrol setelah diberi perlakuan. Kelompok eskperimen mengalami peningkatan rata-rata sebesar 7, sedangkan kelompok kontrol mengalami peningkatan sebesar 6. Terlihat bahwa rata-rata kelompok eksperimen menunjukkan peningkatan yang lebih besar dibandingkan kelompok kontrol.

Berdasarkan data yang diperoleh, untuk melihat perbedaan dilakukan uji hipotesis menggunakan independent sample t-test. Salah satu syarat menggunakan t-test yaitu data merupakan data parametrik, kemudian data parametrik mempunyai sebaran data yang normal dan homogen.

Tabel. 6 Hasil Uji Hipotesis

\begin{tabular}{llll}
\hline Test & Kelompok & $\mathrm{M}$ & Sig. (2-tailed) \\
\hline \multirow{2}{*}{ Pretest } & Eksperimen & 15,61 & \multirow{2}{*}{0,446} \\
& Kontrol & 15,14 & \\
\multirow{2}{*}{ Posttest } & Eksperimen & 22,00 & 0,613 \\
& Kontrol & 21,44 & \multirow{2}{*}{} \\
\hline
\end{tabular}

Tabel 6 menunjukkan bahwa data pretest dan posttest memiliki hasil signifikansi yang berbeda. Data pretest atau keadaan awal memiliki hasil signifikansi 0,446 > 0,05 yang berarti $\mathrm{H}_{0}$ diterima, yaitu pendekatan saintifik terhadap kemampuan pemecahan masalah anak usia 3-6 tahun tidak efektif. Hal tersebut dikarenakan kedua kelompok belum mendapatkan 
perlakuan. Data posttest atau keadaan akhir memiliki hasil signifikansi 0,613<0,05 yang berarti $\mathrm{H}_{1}$ diterima, yaitu pendekatan saintifik terhadap kemampuan pemecahan masalah anak usia 3-6 tahun memiliki efektivitas. Anak-anak mampu memberikan solusi terhadap masalah yang anak temui, mengerti sebab akibat masalah terjadi seperti contoh setelah diberikan pembelajaran menggunakan pendekatan saintifik.

\section{Pembahasan}

Metode pendekatan saintifik dapat berkontribusi secara positif dalam meningkatkan kemampuan pemecahan masalah anak usia 3-6 tahun dilihat dari hasil data penelitian yang telah dipaparkan bahwa data akhir memiliki hasil signifikansi 0,613 $<0,05$ yang berarti $\mathrm{H}_{1}$ diterima, yaitu pendekatan saintifik terhadap kemampuan pemecahan masalah anak usia 3-6 tahun memiliki efektivitas. Kegiatan yang dilakukan anak diajak untuk memecahkan masalah yang terdapat dalam dirinya secara aktif dan bersama-sama. Berdasarkan hasil pretest dan posttest yang dilakukan peneliti, hasil dari pretest memiliki peningkatan pada waktu posttest. Sebelum menentukan pretest peneliti mengambil populasi sebanyak 61 anak dari kelompok B. Berdasarkan wawancara dan observasi dapat ditarik kesimpulan bahwa rata-rata dalam populasi tersebut memiliki kemampuan pemecahan masalah yang rendah, sehingga sampel dalam penelitian memenuhi karakteristik sampel yang akan diteliti. Terdapat beberapa landasan bahwa metode pendekatan saintifik dapat meningkatkan kemampuan pemecahan masalah pada anak usia dini.

Pertama, dalam kegiatan ini anak diajak secara aktif untuk memahami suatu masalah. Pemahaman masalah berkaitan dengan proses identifikasi terhadap apa saja yang diketahui dan apa yang ditanyakan. Pada langkah ini memerlukan suatu kecermatan agar pemahaman yang dihasilkan tidak sampai berbeda dengan permasalahan yang sedang dihadapi (Chronopoulou \& Riga, 2012). Hal ini terbukti pada saat guru memberikan pertanyaan mengenai sebuah masalah seperti "bagimana cara membebaskan stroberi yang terjebak didalam es batu?", kemudian anak A dan anak B mampu memberikan argumentasinya terhadap pertanyaan yang diberikan guru saat itu. Anak yang tidak dapat menjawab pertanyaan mendapatkan skor 1 , anak memberikan solusi dengan menggunakan jawaban fantasi mendapatkan skor 2, anak memberikan 1 solusi yang efektif mendapatkan skor 3, anak mampu memberikan 2 solusi yang efektif mendapatkan skor 4 .

Kedua, setelah hal-hal yang diketahui dan ditanyakan dirumuskan, langkah selanjutnya adalah melakukan perencanaan penyelesaian. Langkah ini berkenaan dengan pengorganisasian konsep-konsep yang bersesuaian untuk menyusun strategi, termasuk didalamnya penentuan sarana yang dipergunakan dalam penyelesaian masalah (Chronopoulou \& Riga, 2012). Hasil penelitian dibuktikan pada saat anak diberikan sebuah masalah, anak secara aktif mencari sebab-akibatnya dengan menghubungannya dengan pengalaman yang pernah anak alami. Anak yang tidak dapat menjawab pertanyaan mendapatkan skor 1, anak memberikan solusi dengan menggunakan jawaban fantasi mendapatkan skor 2, anak memberikan 1 solusi yang efektif mendapatkan skor 3, anak mampu memberikan 2 solusi yang efektif mendapatkan skor 4 .

Ketiga, pelaksanaan rencana penyelesaian akan menghasilkan sebuah jawaban atas pertanyaan dalam masalah. Jawaban tersebut kemudian dicek kembali kebenarannya. Pengecekan ini dilakukan dengan menstubstitusikan jawaban ke dalam model masalah (Doğru \& Şeker, 2012). Hasil penelitian dibuktikan dengan kegiatan mengeksplor dan membuktikan argumen yang telah anak paparkan, seperti ketika anak diberikan sebuah es batu yang didalamnya terdapat stoberi anak bergegas mencari cara bagaimana agar stoberi terlepas dari dalam es batu tersebut. Ada anak yang melakukannya dengan cara menaruh es batu dibawah sinar matahari atau memasukkan es batu kedalam air kemudian diaduk, maupun memukul es batu menggunakan batu. Anak yang tidak dapat menjawab pertanyaan mendapatkan skor 1, anak memberikan solusi dengan menggunakan jawaban fantasi 
mendapatkan skor 2, anak memberikan 1 solusi yang efektif mendapatkan skor 3, anak mampu memberikan 2 solusi yang efektif mendapatkan skor 4

Pembelajaran menggunakan metode pendekatan saintifik dapat memberikan pengaruh yang positif dalam pembelajaran guru untuk mengajarkan pemecahan masalah pada anak usia dini. Pembelajaran menggunakan pendekatan saintifik dapat mengarahkan pemahaman anak tentang pemecahan masalah yang telah mereka pelajari dan pahami sebelumnya. Saat anak-anak memahami cara menyelesaikan pemecahan masalah sederhana yang terdapat dalam dirinya maka anak dapat menyelesaikan masalah dalam kehidupan sehari-hari (Doğru \& Şeker, 2012). Contohnya dalam kegiatan proses identifikasi terhadap apa saja yang diketahui dan apa yang ditanyakan untuk memahami sebuah masalah beberapa anak terlihat mengeluarkan pendapat dan argumenya. Pada kegiatan tersebut terlihat bagaimana anak mencari sebab akibat dan solusi yang kemudian didiskusikan bersama-sama .

Penelitian menggunakan metode pendekatan saintifik mendukung penelitian sebelumnya bahwa pemecahan masalah dapat berpengaruh kepada kemampuan anak-anak untuk menghasilkan solusi untuk masalah yang berhubungan dengan sains, dan bagaimana kemampuan ini berhubungan dengan aspek perkembangan kognitif lainnya, yaitu, kecenderungan anak untuk mengajukan pertanyaan, dan penggunaan sains- berdasarkan ide selama pemecahan masalah (Fusaro \& Smith, 2018). Selain itu penelitian (Wallace \& Russ, 2015) yang menjelaskan bahwa proses pendekatan saintifik dapat meningkatkan pemahaman peserta didik akan menanggapi dengan lancar sebuah masalah, yaitu, dengan banyak solusi, dapat memanfaatkan keterampilan kognitif yang relevan, seperti pemikiran yang berbeda, imajinativitas dalam merancang solusi, dan keterbukaan untuk mendekati masalah.

Pada masa perkembangan, anak dapat memecahkan masalah sesuai dengan solusi yang efektif. Pendekatan saintifik sesuai dengan hasil posttest yang menunjukan adanya pengaruh yang positif terhadap pemecahan masalah anak usia dini. Hasil penelitian ini dapat digunakan sebagai salah satu metode yang efektif bagi pengembangan pemecahan masalah pada saat anak memasuki masa usia dini. Pada usia dini, konsep pemecahan masalah harus diberikan sesuai dengan kemampuan anak agar dimasa dewasa anak dapat bertindak sesuai dengan sesuai dalam memecahkan sebuah masalah. Pada usia dini pemecahan masalah dapat berpengaruh pada perilaku anak dimasa mendatang. Pembelajaran menggunakan pendekatan saintifik dapat diberikan dalam ranah pendidikan anak usia dini karena dalam metode ini anak dilibatkan langsung dalam cara memecahkan sebuah masalah. Pembelajaran menggunakan pendekatan saintifik dapat memberikan manfaat yang positif bagi anak usia dini, karena anak secara aktif terlibat langsung dalam kegiatan pembelajaran dan kegiatanya berpusat pada anak dan guru hanya bertugas sebagai fasilitator untuk anak. Pentingnya mengembangkan kemampuan pemecahan masalah anak sejak dini berkaitan dengan tuntutan pendidikan anak usia dini. Sebab anak harus berani menghadapi berbagai permasalahan sederhana yang muncul di kehidupan sehari-harinya (Widiastuti et al., 2018). Saat anak mengerti dan memahami sebuah masalah yang mereka hadapi diharapkan cara memecahkan masalah tersebut tertanam dalam diri mereka dan dapat diterapkan dalam perkembanganya menjadi manusia dewasa.

\section{SIMPULAN}

Penerapan pendekatan saintifik sangat efektif terhadap kemampuan pemecahan masalah yang telah diterapkan di TK ABA Thoyibah Banyuanyar. Selain itu, terlihat dari cara anak dalam memberikan solusi pada suatu masalah yang telah mereka hadapi dan dapat memahami sebab akibat yang terjadi. Oleh karena itu, dapat dibuktikan bahwa pendekatan saintifik mempunyai pengaruh yang positif terhadap kemampuan pemecahan masalah bagi anak. Bagi peneliti selanjutnya diharapkan dapat memperluas kajian penelitian sehingga nantinya mampu mengkaji lebih mendalam terkait dengan penerapan pendekatan saintifik dan kemampuan pemecahan masalah. 


\section{UCAPAN TERIMA KASIH}

Ucapan terimakasih disampaikan oleh penulis kepada seluruh pihak yang telah membantu dan mendukung dalam proses pembuatan artikel jurnal ini terutama pada TK ABA Thoyibah Banyuanyar yang sudah bekerjasama dan mengizinkan peneliti untuk melakukan penelitian di lembaga tersebut.

\section{DAFTAR PUSTAKA}

Anshori, A. (2018). 68 Model Pembelajaran Inovatif dalam Kurikulum 2013. Yogyakarta: ARRUZZ MEDIA.

Chronopoulou, E., \& Riga, V. (2012). The Contribution of Music and Movement Activities to Creative Thinking in Pre-School Children. Creative Education, 03(02), 196-204. https:// doi.org/10.4236/ce.2012.32031

Couchenour, D., \& Chrisman, J. K. (2016). Reasoning and Problem Solving. In The SAGE Encyclopedia of Contemporary Early Childhood Education (Nomor May 2016, hal. 80-105). https:// doi.org/10.4135/9781483340333.n340

Doğru, M., \& Şeker, F. (2012). The effect of science activities on concept acquisition of age 5-6 children groups. Kuram ve Uygulamada Egitim Bilimleri, 12(SUPPL. 4), 3011-3024.

Fleer, M. (2019). Scientific Playworlds: a Model of Teaching Science in Play-Based Settings. Research in Science Education, 49(5), 1257-1278. https://doi.org/10.1007/s11165-0179653-z

Fusaro, M., \& Smith, M. C. (2018). Preschoolers' inquisitiveness and science-relevant problem solving. Early Childhood Research Quarterly, 42, 119-127. https:// doi.org/10.1016/j.ecresq.2017.09.002

Hong, S. Y., \& Diamond, K. E. (2012). Two approaches to teaching young children science concepts, vocabulary, and scientific problem-solving skills. Early Childhood Research Quarterly, 27(2), 295-305. https://doi.org/10.1016/j.ecresq.2011.09.006

Hudojo, H. (2001). Pengembangan kurikulum dan pembelajaran matematika. Universitas Negeri Malang.

Istiningsih. (2014). Relationship between Religious Consciousnesses with Scientific $\backslash$ nLearning (Case Study in Islamic Basic School in Malaysia and Indonesia) \n. IOSR Journal of Research \& Method in Education (IOSR-JRME), 4(6), 27-33. https:// doi.org/10.9790/7388-04642733

Juhji, J. (2016). Pembelajaran Sains Pada Anak Raudhatul Athfal. aș-șibyān: Jurnal Pendidikan $\begin{array}{llll}\text { Anak Usia Dini, 1(1), 49-59. } & \text {. }\end{array}$ http://jurnal.uinbanten.ac.id/index.php/assibyan/article/view/192

Peraturan Menteri Pendidikan dan Kebudayaan Republik Indonesia Nomor 146 Tahun 2014 Tentang Kurikukum 2013 Pendidikan Anak Usia Dini, Kemendikbud Pendidikan Anak Usis Dini (2013).

Lazim, M. (2013). Penerapan Pendekatan Saintifik dalam Pembelajaran. 1-13.

Made, W. (2011). Strategi Pembelajaran Inovatif Kontemporer: Suatu Tinjauan. Konseptual Operasional. Jakarta: PT. Bumi Aksara.

Marwah, M., Rahamma, T., \& Nadjib, M. (2018). Pendekatan Saintifik Dalam Pengembangan Bahasa Anak Di Taman Kanak-Kanak Asoka Kota Makassar. KAREBA : Jurnal Ilmu Komunikasi, 6(2), 249. https://doi.org/10.31947/kjik.v6i2.5322

Patmonodewo, S. (2000). Pendidikan anak prasekolah. Pedagogik: Jurnal Pendidikan, pendidikan pra sekolah, 33. http://library.walisongo.ac.id/digilib/files/disk1/9/jtptiain-gdl-s12005-sitifaidah-403-Bab2_310-4.pdf

Pemerintah Republik Indonesia. (2003). Undang -Undang Republik Indonesia Nomor 20 Tahun 2003. In Pemerintah Republik Indoensia.

Rusman. (2015). Pembelajaran Tematik Terpadu: Teori, Praktik dan Penilaian. Rajawali Press. https:// doi.org/10.1016/j.matdes.2019.107759

Sari, W. W., Nuryadin, S., \& Sujiono, Y. N. (2014). Peningkatan Kemampuan Sains melalui 
DOI: $10.31004 /$ obsesi.v5i2.1048

Pendekatan Proyek. Jurnal Pendidikan Usia Dini, 8(1), 55-64.

Suyanto, S. (2006). Pengenalan Sains Untuk Anak Tk Dengan Pendekatan "Open Inquiry." http://staff.uny.ac.id/sites/default/files/Pengenalan Sains Untuk Anak Tk(1).pdf

Van Vreden, M. (2018). Music-inspired free play to foster scientific exploration in early childhood. South African Journal of Childhood Education, 8(2). https:// doi.org/10.4102/sajce.v8i2.560

Wallace, C. E., \& Russ, S. W. (2015). Pretend play, divergent thinking, and math achievement in girls: A longitudinal study. Psychology of Aesthetics, Creativity, and the Arts, 9(3), 296305. https:/ / doi.org/10.1037/a0039006

Washington, D. (1996). National Science Education Standards. In עלון הנוטע (Vol. 66, Nomor December).

Widiastuti, E., Tegeh, I. M., \& Ujiant, P. R. (2018). Pengaruh Pendekatan Saintifik terhadap Kemampuan Pemecahan Masalah pada Anak Kelompok B di Taman Kanak-Kanak. Jurnal Pendidikan Anak Usia Dini Undiksha. https:/ / doi.org/10.23887/ paud.v6i2.15314

Yunita, H., Meilanie, S. M., \& Fahrurrozi, F. (2019). Meningkatkan Kemampuan Berpikir Kritis melalui Pendekatan Saintifik. Jurnal Obsesi : Jurnal Pendidikan Anak Usia Dini, 3(2), 425. https://doi.org/10.31004/obsesi.v3i2.228

Yusri, N. (2015). Keterkaitan Scientifik learning dengan kemampuan berfikir kritis. Universitas Islam Negeri Sultan Syarif Kasim Riau.

Zelazo, P. D. (2015). Executive function: Reflection, iterative reprocessing, complexity, and the developing brain. Developmental Review, 38, 55-68. https://doi.org/10.1016/j.dr.2015.07.001 